Article

\title{
Global Sustainability Crossroads: A Participatory Simulation Game to Educate in the Energy and Sustainability Challenges of the 21st Century
}

\author{
Iñigo Capellán-Pérez ${ }^{1,2, * \mathbb{D}}$, David Álvarez-Antelo ${ }^{1}$ and Luis J. Miguel ${ }^{1,2}$ \\ 1 Research Group on Energy, Economy and System Dynamics, Escuela de Ingenierías Industriales, \\ Paseo del Cauce s/n, University of Valladolid, 47011 Valladolid, Spain \\ 2 Systems Engineering and Automatic Control, Escuela de Ingenierías Industriales, Paseo del Cauce s/n, \\ University of Valladolid, 47011 Valladolid, Spain \\ * Correspondence: inigo.capellan@uva.es
}

Received: 13 June 2019; Accepted: 2 July 2019; Published: 4 July 2019

\begin{abstract}
There is a general need to facilitate citizens' understanding of the global sustainability problem with the dual purpose of raising their awareness of the seriousness of the problem and helping them get closer to understanding the complexity of the solutions. Here, the design and application of the participatory simulation game Global Sustainability Crossroads is described, based on a global state-of-the-art energy-economy-environment model, which creates a virtual scenario where the participants are confronted with the design of climate mitigation strategies as well as the social, economic, and environmental consequences of decisions. The novelty of the game rests on the global scope and the representation of the drivers of anthropogenic emissions within the MEDEAS-World model, combined with a participatory simulation group dynamic flexible enough to be adapted to a diversity of contexts and participants. The performance of 13 game workshops with 420 players has shown it has a significant pedagogical potential: the game is able to generate discussions on crucial topics which are usually outside the public realm such as the relationship between economic growth and sustainability, the role of technology, how human desires are limited by biophysical constraints or the possibility of climate tipping points.
\end{abstract}

Keywords: gamification; modelling; climate change; environmental education; participatory simulation

\section{Introduction}

The ongoing sustainability crisis is a very complex problem which requires urgent and radical control measures globally [1-5]. By accelerating biodiversity loss, increased alteration in such natural cycles as carbon (climate change), nitrogen, or phosphorus, intensifying the degradation of ecosystems, etc., human societies are degrading the natural life-support systems and processes upon which we depend to sustain our own existence. Earth tipping points, which refer to a critical threshold at which a tiny perturbation can qualitatively alter the state or development of a component of the Earth's system, may be trespassed in the next few deaces, implying large-scale impacts (dangerous, even catastrophic) for human and ecological systems [6]. Consequently, we are risking the continuity of our societies as we know them [3,7-9].

The transition to sustainability is thus a challenge that is global and political in nature. Moreover, no country has been found to meet basic needs for its citizens at a globally sustainable level of resource use [10]. Hence, we as members of most human societies, and especially those from the global North, have a responsibility and duty to change our behavior and values so that we can cover our needs and desires while not overusing natural resources or degrading the environment and biosphere processes 
irreversibly (on a human life time scale). Hence, to be effective, policy sustainability measures will require the active cooperation of the population from very different socio-economic contexts and regions to modify their individual patterns of consumption, as well as to comply and collaborate with the political measures promoted by political institutions. There is, therefore, a need to facilitate citizens' understanding of the sustainability conundrum, with the dual purpose of raising their awareness of the seriousness of the problem and, at the same time, helping them get closer to understanding the complexity of the solutions. Education of future generations in these concepts is also key for achieving future sustainable pathways [11].

The comprehension of the sustainability conundrum is challenged by the fact that human societies and biosphere form complex systems which are "dynamic, tightly coupled, governed by feedback, nonlinear, self-organizing, adaptive, and evolving", while "our mental models tend to be static and narrow" in time, space, and affected interconnections [12]. In fact, mental models of complex systems may be biased by wrong information, but also by non-explicit factors such as ignorance, vested interests, judgmental errors, and biases. Hence, mental models are likely to incorrectly represent the dynamics of the human/nature interface [12-14]. These simplistic models can be described as "cognitive illusions" which hinder the correct understanding of such dynamics. The limitations to understanding complex systems hinder in turn our capability to propose effective policy measures for the sustainability crisis $[13,15-18]$. In fact, previous research has shown that not only pupils of all ages, but also their teachers hold many misconceptions and misunderstandings concerning these issues [19].

After four decades of international environmental policy and governance following the first Earth summit held in Stockholm in 1972 [20], intensified over the last 20 years (Earth Summit in Rio de Janeiro in 1992 [21], the United Nations Framework Convention on Climate Change [22], the Convention on Biological Diversity [23], the Sustainable Development Goals [24], etc.), human societies are today increasingly degrading the environment $[4,5,25]$. Hence, unsustainability trends have not been reversed (increasing levels of energy consumption and greenhouse gas (GHG) emissions, forest and biodiversity loss, etc.), which reveals that the main drivers of unsustainability are still not being addressed. The ineffectiveness of current environmental policies has been associated with a focus on "symptoms", revealing "a widespread failure of systems thinking" [12].

On the other hand, researchers have indicated the disadvantages of traditional science teaching, namely that students' interest and willingness to study science is likely to be diminished when their learning is decontextualized and requires mainly rote memorization. As a result, students are not prepared with the knowledge and abilities needed for the 21st century such as critical thinking and problem-solving abilities. To address this problem, learning by playing digital games in the context of participatory simulations has been advocated as a promising approach to implementing science education [26,27]. In particular, computational advances support the modelling and study of complex scientific phenomena, making it possible to study events with complex causes and outcomes $[18,28]$.

Gamification is the application of game-design elements and game principles to non-game contexts with the objective of advancing outcomes in understanding and behavior of the participants. Active participation in the process and additional motivation are some of these advantages that facilitate learning in comparison to more conventional methods. Participants feel that they own and control their learning, are free to fail and try again without negative repercussions: the players make their own decisions and see the impacts of these decisions. Games allow for envisioning and seeing the consequences of actions at different points in time, delivering experiences that tap into a range of human emotions, from fear and aggression to joy and wonder. Hence, gamification allows work to be done on the attitudes, knowledge and values that are promoted in development education, awareness raising and education for global citizenship. However, the usefulness of this approach should be assessed in a per case basis; gamification may not be effective for every learner or every learning situation [29-34].

In the last few decades, a diversity of games focusing on sustainability have been designed and successfully applied with the purpose of facilitating the understanding of such environmental issues 
as water conservation, climate change, and pollution, on different scales (local vs regional vs global) varying greatly in format, technical sophistication and scientific accuracy [34,35]. This work describes the participatory simulation game Global Sustainability Crossroads, which represents an advancement with relation to already existing games through its global scope and dynamic modelling of the drivers of anthropogenic emissions, which are embedded in a dynamic participatory simulation flexible enough to be adapted to a diversity of contexts. The game is based on the MEDEAS-World model, which is a state-of-the-art global, one-region energy-economy-environment model (or integrated assessment model) designed applying System Dynamics [36]. This methodology has proved to be particularly well adapted to properly understand and address the multiple and interlinked factors involved in the sustainability crisis and avoid "policy resistance", i.e., the tendency for an intervention to be defeated by the system's response to the intervention itself [12-14,37]. The MEDEAS-World model considers numerous connections between the economic, energetic, and environmental systems, linking the biophysical constraints (availability of materials, land and net energy; climate change impacts, etc.) with the economic system.

Although, in the real world, policies are implemented at local/national level, environmental constraints are global. Thus, any policy towards sustainability must take into account the popular ecologist axiom "think global, act local" in order to be effective. Thus, the objective of both the model and the game presented in this paper is to provide orientation towards strategic planning rather than to provide precise and detailed policy recommendations. What are the feasible/unfeasible strategies to successfully achieve the transition towards an energy sustainable system? What are the ethical dilemmas of this transition? What are the implications of taking different alternative routes being proposed in the scientific-political realms, such as Green Growth (e.g., [38,39]) or Degrowth (e.g., [40])? The developed game allows other relevant objectives to be fulfilled, such as contributing to closing the gap between scientific research and civil society (i.e., scientific dissemination), as well as familiarizing the general public with deliberative participatory methods.

The objectives of the paper are to describe the game dynamics of Global Sustainability Crossroads and to qualitatively evaluate its pedagogical potential in three dimensions: to communicate the roots and seriousness of the sustainability crisis and frame potential solutions, to bridge the gap between science and society and to contribute to bring to public discussion the social choices to be taken under uncertainty in the next few decades.

The text is structured as follows: Section 2 describes the developed participatory game, including a brief overview of the model upon which the game is based, Section 3 reports the main insights gained after the performance of the game in terms of pedagogical capacity, and Section 4 concludes.

\section{Methodology}

This section covers the methodological background and novelty of the developed participatory simulation game Global Sustainability Crossroads, as well as it describes the game dynamic and the graphical interface.

\subsection{Methodological Background and Novelty}

Games with sustainable development themes have developed steadily in the academic world over approximately the last fifteen years and gamification has become progressively widespread since it first appeared [34,35]. In relation to model-based simulation games focusing on sustainability, climate mitigation and the transition to renewable energies, the field was opened in the 1980s, and has been increasing ever since. Some relevant examples are:

- STRATEGEM: computer-assisted game based on the World3 simulation model [41-43], with the difference that STRATEGEM only represents one region (i.e., includes trade) and covers a time span of 60 years [44-46]; 
- FISHBANKS: The original version was created in 1986. Multiplayer simulation game in which participants play the role of fishermen and seek to maximize their net worth as they compete against other players and deal with variations in fish stocks and their catch [47];

- LA Water Game: Educational simulation game that teaches the management of aging water infrastructures in the city of Los Angeles (USA) [48];

- World Climate: This game provides an interactive role-play experience through which participants take on the roles of delegates to the UN climate negotiations and are challenged to create an agreement that meets international climate goals. Their decisions are entered in the C-ROADS model, which provides immediate feedback about expected global climate impacts, enabling them to learn about climate change while experiencing the social dynamics of negotiations $[49,50]$ (Lucas et al., [51] propose a similar game although without applying a model);

- World Energy: A climate and energy role-playing negotiation game that promotes understanding of the causes of World Climate Change and the factors that could mitigate it using the EN-ROADS model as a basis. The main objective of the game is to reach agreement between the different parties to limit climate change and ensure that the global average temperature rise in the year 2100 is less than $2{ }^{\circ} \mathrm{C}[52]$.

Global Sustainability Crossroads represents an advancement with relation to already existing games through its global scope and dynamic modelling of the drivers of anthropogenic emissions, which are embedded in a dynamic participatory simulation. The game is based on the MEDEAS-World model (see Appendix A), which is a state-of-the-art one-region integrated assessment model originally developed to provide policy-guidance within the UE through the homonymous project (https://www.medeas.eu/). The model has been designed applying System Dynamics [36], which has proved to be a methodology particularly well adapted to properly understand and address the multiple and interlinked factors involved in the sustainability crisis and avoid "policy resistance" [12-14,37]. The model considers numerous connections between the economic, energetic and environmental systems which allows a simplified representation of the complexity of the energy-economy-climate system relationships. Identifying the human-natural system as a complex system, the modelling strategy focuses rather on the interactions (feedback) between the components of the system rather than the detail of the components themselves. The standard global model [36] was complemented with some features to improve the range of features in the game, such as the possibility that 5 different climate tipping points may be surpassed; each simulation equates to "rolling the dice" (probabilities derived from [53]).

The game has been designed to include all three sustainability's triple-bottom line dimensions: economic, social and environmental dimension [35], as well as following Chen and Martin's [54] criteria to enhance the pedagogical capacity of environmental education: (1) it is aimed at change and not just knowledge attainment, (2) reveals behavior patterns in a real-world context, (3) highlights both internal and external influences on current environmental behavior, and (4) includes an interactive problem-solving approach that demands a solution.

The developed flexible dynamic which can be adapted in a case per case basis by the facilitators of the sessions allows a broad target public, from non-experts to experts and policy-makers, starting from high school.

\subsection{Description of the "Global Sustainability Crossroads" Game}

The game has two main phases: (1) simulation, and (2) assembly, debriefing and conclusions (see Figure 1). 


\section{Group playing}

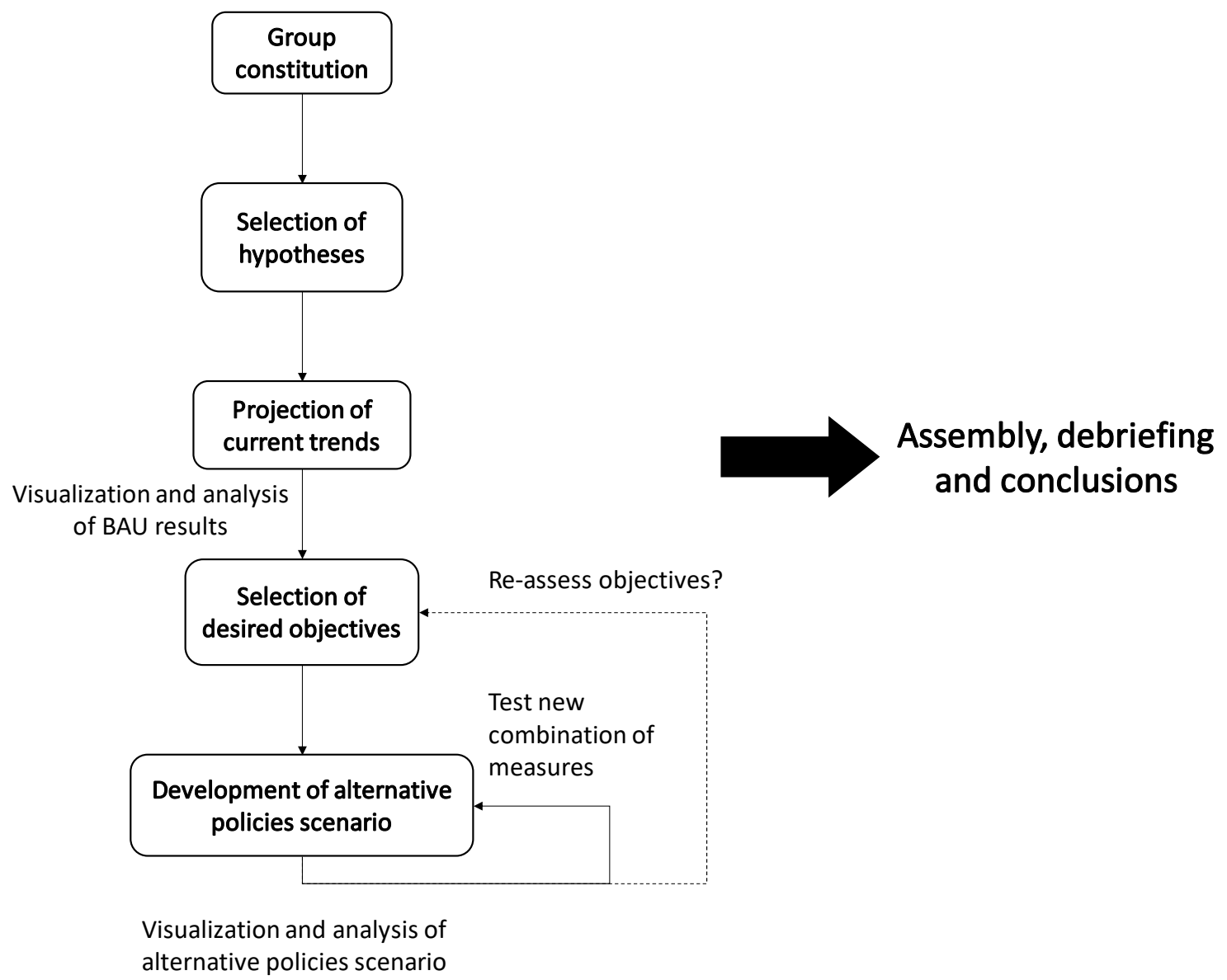

Figure 1. Steps of the Global Sustainability Crossroads game. See Supplementary Material for the forms used in the game. BAU: Business-As-Usual.

The game unfolds as follows:

Group constitution: A secretary and spokesperson are chosen per group, with the roles of noting the agreements and choices made, and reporting to the Assembly, respectively. One facilitator is assigned by group to guide the game dynamics, run the game interface as well as to solve the eventual technical and conceptual questions which may arise during the game.

Selection of hypotheses: Hypotheses refer to assumptions which are subject to uncertainty and frame the context in which the human decisions will have to be taken in the future. Differently from the policy target measures, these are factors which cannot be affected by human decisions. Thus, once set up by each group, hypotheses cannot be modified during the game. The participants are allowed to decide over two hypotheses: the availability of non-renewable energy resources (oil, gas, coal, and uranium) and climate change damages. To help the participants select the options, the scientific state-of-the-art for both topics is briefly overviewed [36,55]. For the sake of simplicity and considering time constraints, other hypotheses are usually kept fixed, although in modified versions of the game these could also be incorporated (e.g., techno-sustainable potential of renewable energies, climate sensitivity, etc.). The Supplementary Material includes the form filled in this step (FORM1-HYP).

Projection of current trends: The game invites the participants, by teams, to project current trends into the future (i.e., in technical argot, to develop their Business-As-Usual, BAU, scenario). With the assistance of a facilitator per group, they can select future trends for social, political, technological and economic variables in 12 dimensions belonging to different areas (economy, population, energy 
technologies, technological improvement, transportation, mineral recycling, etc.). The choices taken for each option by the group are marked by the secretary in forms printed on paper. In order to select a consistent set of choices, it is important that the participants envision which "plot" (narrative or storyline in the language of Global Environmental Assessments [56]) broadly corresponds to the future they envision. The Supplementary Material includes the form filled in this step (FORM2-BAU).

Visualization and analysis of BAU results: The choices selected by the team are introduced in the game interface in order to run the corresponding simulation. The main outcomes are presented to the players by the facilitator which clarifies the eventual raised points. This phase allows the participants to understand the main drivers and dynamics behind unsustainable trends which are the base upon with starting to develop alternative pathways.

Selection of desired objectives: In the light of the obtained social and environmental outcomes in the mid-21st Century, each team has to come up with at least two objectives in terms of welfare and environmental sustainability, although the participants are free to enlarge the list of objectives as the game unfolds. This vision corresponds with the concept of "doughnuts economics" [10,57]: just as there are planetary boundaries beyond which lies environmental degradation dangerous for humanity, so too there are social boundaries below which lie resource deprivations that endanger human well-being. The combination of the inner limits of social boundaries and the outer limits of planetary boundaries creates a sustainable space within which all humanity can prosper by pursuing a range of possible sustainable pathways [57]. Hence, the participants are implicitly asked to find a combination of alternative options which would lead all humanity along the safe and just sustainable pathway. The Supplementary Material includes the form filled in this step (FORM3-OBJ).

Development of alternative policy scenario(s): To achieve the desired objectives, players have to develop a consistent alternative narrative making choices for the same 12 social, political, technological, and economic dimensions as in the BAU phase. After a discussion oriented towards reaching consensus within the group, the simulation program shows the results of its decisions. If, in a first attempt, the initial objectives are not reached, the participants can try a new combination of measures (this process iterates until time ends or the objectives are reached). The self-stated objectives may be reconsidered during play. An example scenario pre-configured covering global "basic needs" (>30 GJ/person/year) without reaching dangerous climate change $\left(<1.5^{\circ} \mathrm{C}\right)$ during the timeframe of the analysis was prepared by the developer team in order to be shown to those groups not able to attain their self-stated objectives. The Supplementary Material includes the form filled in this step (FORM4-ALT).

Assembly, debriefing, and conclusions: Group work is followed by an assembly and debriefing where all groups are gathered in the same room, and the spokesperson from each team succinctly presents to the rest of the participants how the game developed for his/her team, which results have been obtained, their reaction and opinion, comments, etc. After the overviews of each group spokesperson', a general discussion ( 20-30 $\mathrm{min}$ ) assisted by the facilitators is set up in order to lead to the take-aways and general conclusions obtained from game playing.

With relation to the desired objectives, global average temperature increase was selected as the reference environmental indicator in the game due to the importance of climate change as a "core" planetary boundary and the absence of other planetary boundaries such as biodiversity loss or disruptions of nitrogen and phosphorus cycles in the applied model [4]. The evaluation of welfare in the simulated scenarios is complicated by the fact that well-being is a very complex concept composed of many dimensions which are not explicitly represented in the MEDEAS-World model (e.g., health, education, system of governance, and equality). As a result, an alternative approach, focused on the relationship between energy and development, had to be taken instead. In fact, an adequate energy supply has been identified as a key prerequisite for economic, cultural and social development in complex societies [58-60]. The review of the literature shows that there is a strong correlation between energy use and living standards at low energy use levels in industrial societies. However, after surpassing a threshold, higher consumption of energy does not distinctly translate into better living standards [61]. Due to these reasons, the final energy use per capita is considered in the game as 
a proxy of well-being (see Table 1). However, the fact that well-being has a strong cultural component has also to be considered. Mentioning the current final energy use per capita at global average level ( $\sim 55 \mathrm{GJ} /$ year/person, i.e., $\sim 15,250 \mathrm{kWh})$ allows the topic of global inequality to be introduced into the game.

Table 1. Final energy use associated to different benchmarks. HDI stands for "Human Development Index", a composite indicator of income, life expectancy and education [62,63]. Source: own elaboration.

\begin{tabular}{cr}
$\begin{array}{c}\text { Final Energy Use } \\
\text { (GJ/Year/Person) }\end{array}$ & Benchmarks \\
\hline 270 & Annual average 1995-2008 final energy footprint of USA [36,61] \\
\hline 135 & Annual average 1995-2008 final energy footprint of the EU [36,61] \\
\hline 75 & HDI > 0.8 for a regression of 40 countries for timespan 1995-2009 [36,61] \\
\hline $30-40$ & $\begin{array}{c}\text { The final energy to cover “basic needs" (adequate nourishment, electricity, water } \\
\text { supply, sanitation and non-slum housing in urban areas) [64]. This also roughly } \\
\text { corresponds to a 0.7 < HDI < 0.8 }\end{array}$ \\
\hline$\sim 25-30$ & Eco-village Sieben Linden (Germany) [65] \\
\hline
\end{tabular}

The horizon of the analysis is set in the mid-century (2050-80) for two main reasons. Firstly, scientific assessments are pointing to the fact that, by then, decarbonization of the global socio-economy should have progressed substantially (<80\% GHG emissions with relation to 1990 following the EU Energy Roadmap [66] or IPCC recommendations [2]), so the measures to avoid dangerous climate change should start promptly. Secondly, from a technology development point of view, new technologies require some decades to evolve from $\mathrm{R} \& \mathrm{D}$ projects to commercial large-scale deployment. This makes it reasonable to consider just current demonstrated technologies.

The game is non-competitive, i.e., the different groups do not compete against each other to obtain the "best" outcomes. This is due to 3 main reasons: (1) each group builds its own BAU, thus the alternative scenarios are not directly comparable, since they aim to correct a different "future"; (2) given the incommensurability of the different dimensions of the sustainability transition (environment, economic, social), an optimum cannot be obtained with the modelling tool; and (3) finally, the authors of the game believe that a shift from the current paradigm based on competition to cooperation will be an indispensable ingredient to achieve sustainable, prosperous and equitable societies in the future. Thus, we believe that the game should be consistent with this view, given that most commercial games are already competitive (as a reflection of current societal values).

Depending on the number of participants, available time and number of facilitators, three versions of the game have been implemented to date: (1) by groups-1 session ( maximum 6-8 participants per group and facilitator), (2) assembly-1 session when the ratio of participants per facilitator is significantly higher, and (3) by groups-several sessions, the latter including reports to be delivered between the sessions to justify the choices taken. The main operative difference between the first 2 versions consists in the way decisions are taken in each case: per group by consensus (although a vote may be forced by the facilitator to unblock the situation), or by vote with the help of printed cards in the assembly version. The third version is substantially more time intensive for the participants and, to date, has been applied experimentally in a subject in an Engineering Faculty (see Table A1).An additional option would be the individual game, which has been performed internally by the members of the research group developing the game (see Discussion, Section 3).

\subsection{Description of the "Global Sustainability Crossroads" Graphical Interface}

The Global Sustainability Crossroads game interface has been developed using the Sable Version 5.1.507 (DEV) (UNICODE) (www.ventanasystems.co.uk) software, which allows the direct use of the systems dynamic models developed with Vensim software. 
Through a navigation system between screens, it is possible to access the different options for the selection of hypotheses and scenario variables, as well as the simulation results graphs.

The first two screens allow the players to select the different options implemented for each one of the hypotheses and the specific policy sectoral targets (see Figure 2). Choices can be closed or open, some policies allowing both the value of the variable involved, such as the year of beginning of the policy, or the achievement of the selected objective to be customized. For some options, such as the renewable energy technologies growth or the future recycling rate of materials, it is possible to indicate the rate individually for each renewable technology or minerals, respectively.

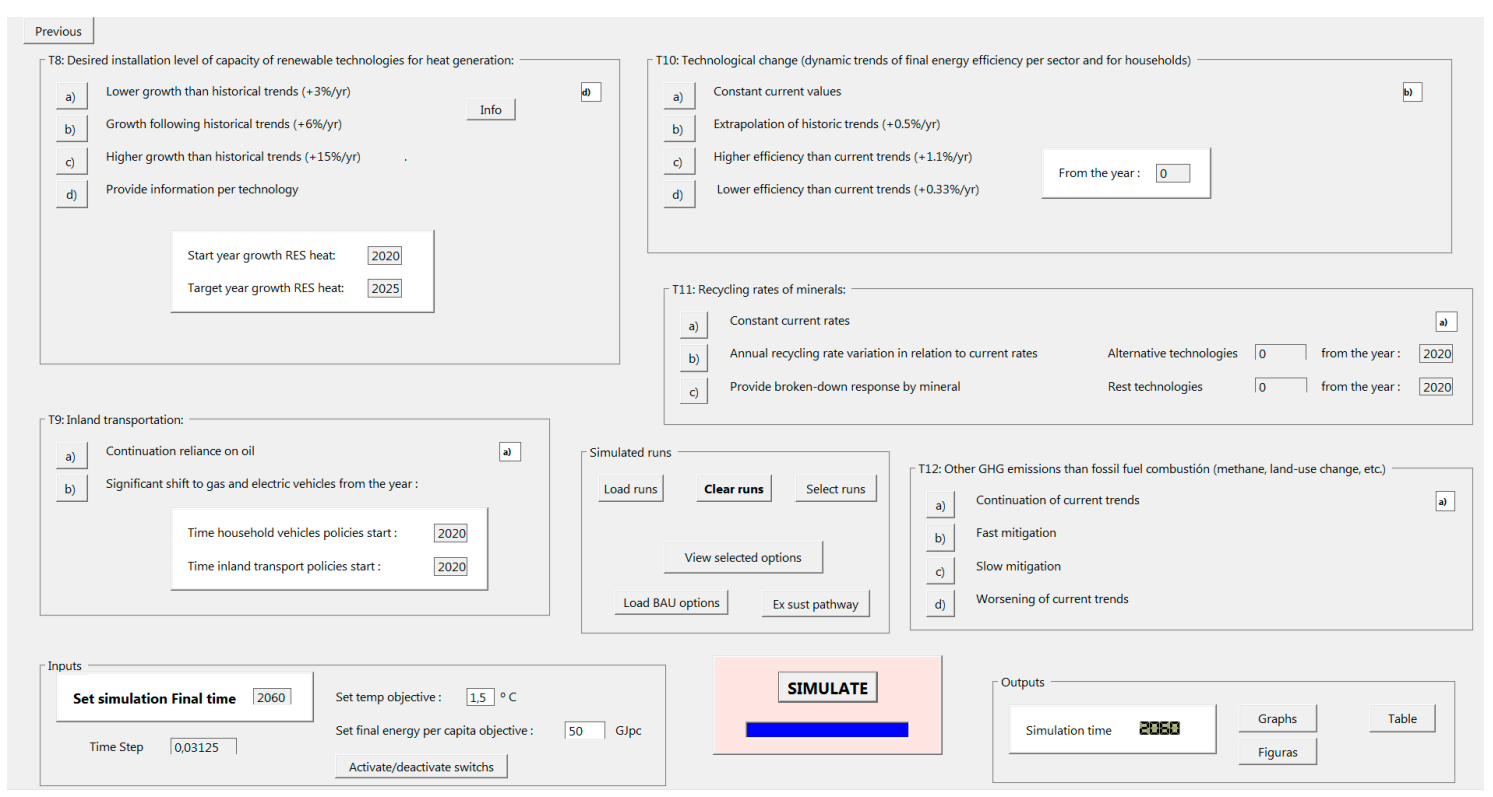

Figure 2. Second screen for selecting hypotheses and inputs to perform a simulation.

After selecting all the options, the facilitators proceed to the simulation of the scenario (it is also possible to choose the final year of the simulation), after which a file with the chosen name will be generated and it is possible to proceed to the results' screens. At this point, it is also possible to load previously saved simulations.

In the results' screens, the first screen shows the level of attainment of the self-stated objectives over time.

The rest of the windows (which can be accessed through the navigation buttons at any time), present different variables of the model that are relevant for understanding the dynamics of the simulated scenario and the reasons for having (or not) reached the objectives:

- Transition to renewables: generation of renewable energy, extraction of non-renewable energies, share of renewables in the energy mix, remaining potential of renewable energy sources.

- Climate dynamics: GHG emissions, $\mathrm{CO} 2$ equivalent (CO2e) concentrations, temperature change, eventual occurrence of climate tipping points.

- Implications: Land requirements for renewables, share of blue water use vs accessible runoff water, gross domestic product per capita (GDPpc), mineral availability, energy return on energy investment (EROI) of the system, total final energy intensity, physical energy intensity.

- Feedback and limits to growth: Annual energy losses due to climate change impacts, variation in energy requirements to compensate for EROI variation, final energy availability, GDPpc (Figure 3).

At any time, it is possible to go back to the options selection screen to see the selected options, simulate a new run or load previously configurated simulations. 


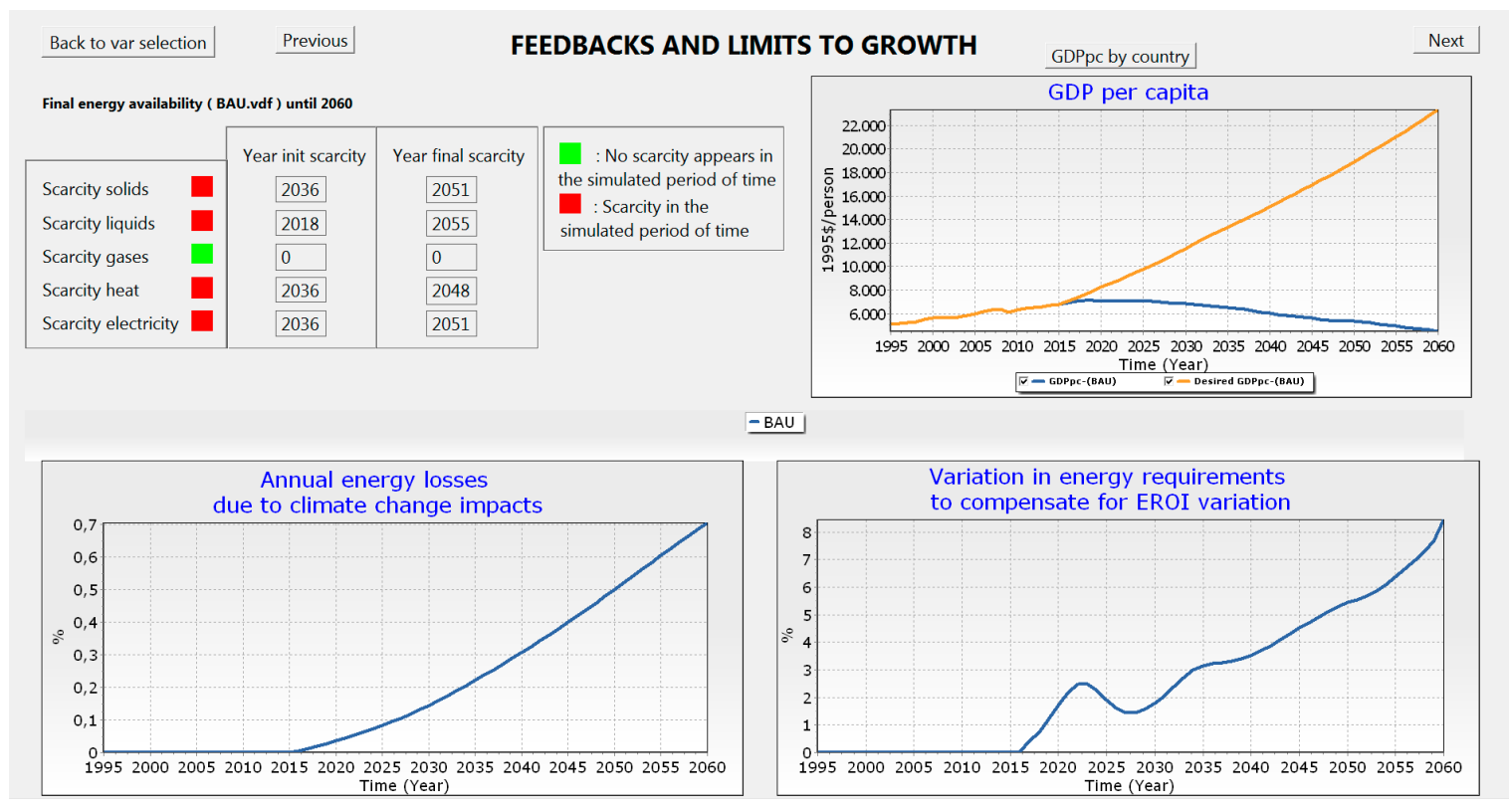

Figure 3. Example of output window: "Feedbacks and limits to growth".

\section{Discussion of Insights from Game Performance}

The Global Sustainability Crossroads game was first played in September 2017 and up to December 2018 a total of 13 sessions with $\sim 420$ participants have been performed in a diversity of contexts with heterogeneous types of participants in terms of nationalities, age, expertise, etc. Players included experts, informed activists, students, and general public of all ages (see Table A1 and Figure 4). Successive workshops and feedback received from participants have allowed to achieve a robust, comprehensive and attractive game for a diversity of players. Also, different variants from the standard main version were developed in order to account for a diversity of contexts and constraints such as time availability. This section qualitatively evaluates the performance of the game in the light of the experience of the workshop sessions carried out to date.

\subsection{Pedagogical Capacity}

As it is well-known, knowledge alone cannot influence the protection of the environment [67]. Global Sustainability Crossroads succeeds in creating a virtual plot where the participants are confronted with the responsibility of finding solutions and designing strategies, as well as with the social, economic, and environmental consequences of their decisions. Hence, players getting into the game experience a deep motivation to solve the problems, stimulating a genuine need to understand the roots of the issues at stake. Simulations allow participants to alter parameters to observe how the system changes at the macro-level (interactions, trade-offs, non-linear effects). The visualizations integrated in the game interface promote inquiry learning.

This section focuses on the pedagogical capacity of the game, qualitatively assessed through the performance of the game sessions, in three dimensions: the understanding of the drivers and consequences of the global sustainability crisis, the capacity to bridge the gap between science and society, and the ability to promote public discussions on the social choices to be taken under uncertainty in the next few decades. 
a

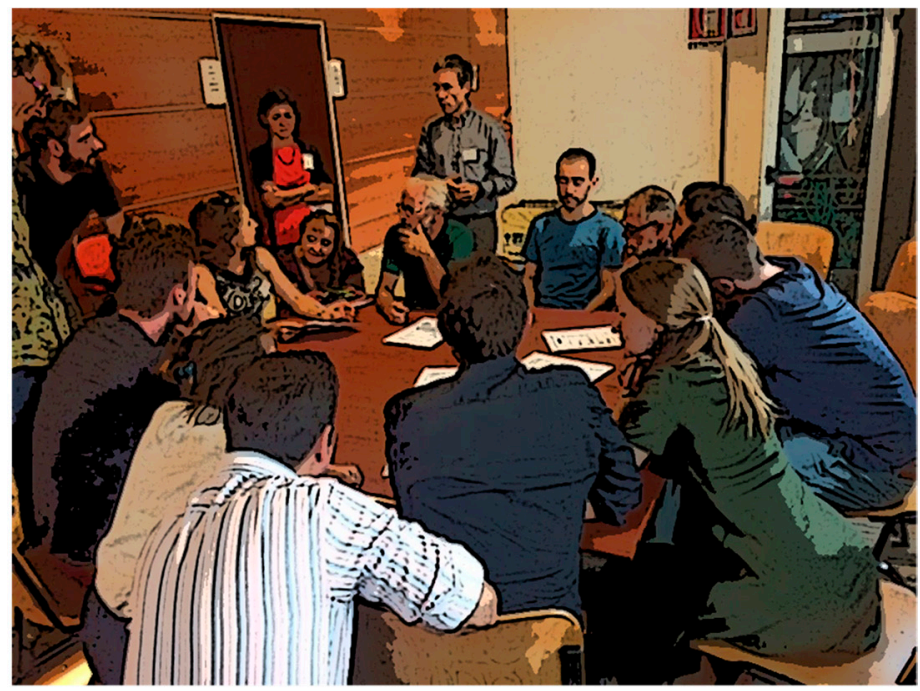

b

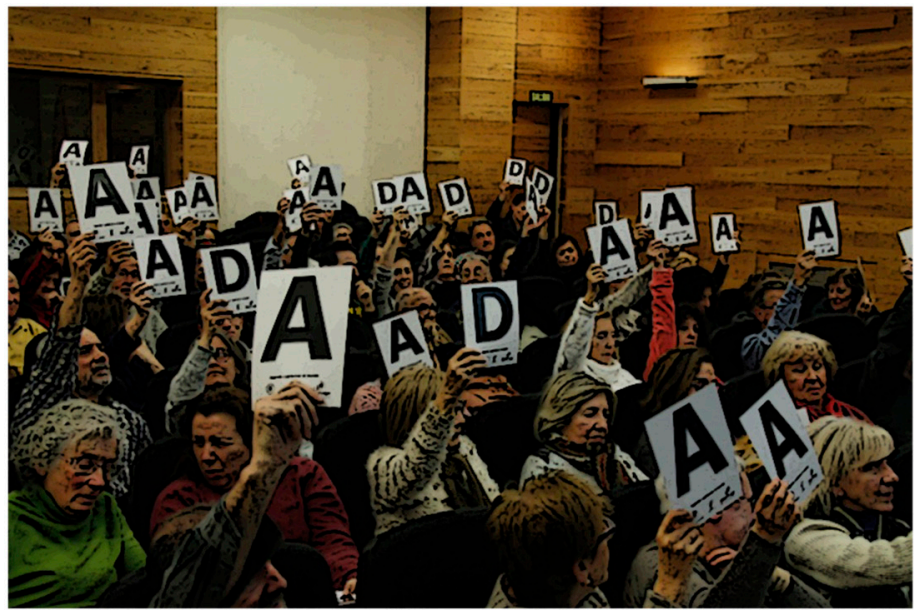

C

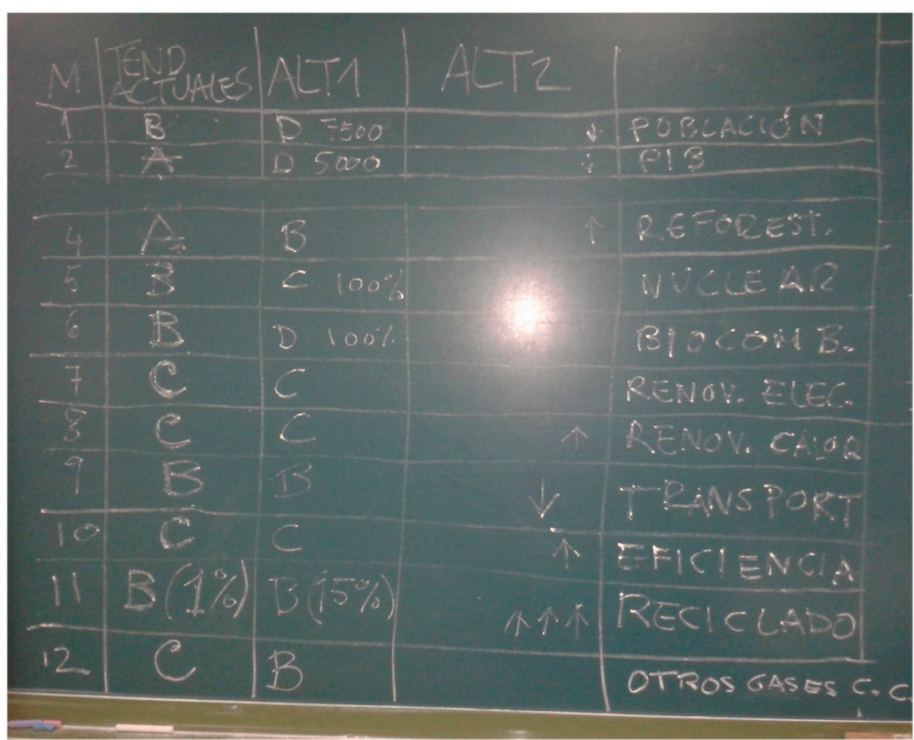

Figure 4. Pictures from 3 of the game workshops performed of Global Sustainability Crossroads: (a) group discussion facilitated by moderators in the Club of Rome Summer Academy (Florence, Italy) (1) (decisions taken by consensus within the group); (b) vote during assembly game workshop during the "Playing to Manage the World" event (Valladolid, Spain); (5) and (c) measures selected for the BAU and two consecutive alternative scenarios by the participants in the assembly game during the 15th Conference and Trade Fair of Green Building (Aínsa, Spain) (6). 


\subsubsection{Understanding the Global Sustainability Crisis and Framing Potential Solutions}

The game allows the players to learn which are the main drivers and consequences of the global sustainability crisis, as well as obtain insights related with the necessary transition such as:

- The importance of the challenge that climate change represents to human societies over the next decades/centuries.

- The identification of economic growth as the main current driver of environmental degradation.

- The fact that climate change and fossil fuel depletion are interrelated issues: energy transition to be performed in a context of declining availability and quality of fossil fuel resources.

- The need of a global fast transition to renewable energy systems.

- The (negative) implications of the transition to renewables: (1) hindering of the EROI of the system, i.e., reducing the net energy delivered to society, and (2) intensification of the competition for other natural resources (land, materials, etc.).

- The assessment that technological changes are necessary, but not sufficient, and must therefore be complemented by significant behavioral, cultural and social changes.

- The existence of trade-offs in the transition to sustainability due to the incommensurability of the different dimensions it is made up of: environmental (e.g., climate mitigation, land-use, and water), economic (monetary investments, welfare, etc.), social (e.g., inequality). Hence, the transition to sustainability will require ethical and even philosophical choices.

- The difficulty of policy-making in a context of uncertainty (e.g., hypotheses of the game and climate tipping points).

- The fact that economic activities and demand are limited by biophysical constraints.

The application of the complex systems approach in the game allows the participants to comprehend the main dynamics of the global energy-economy-climate system through identifying feedback processes, accumulation and inertia mechanisms, time delays and nonlinearities. Some of the counter-intuitive results which attracted the attention of the players on which the game sheds light on were:

- Why the policy targets have not been reached? (interaction of the aforementioned time scarcity with biophysical constraints such as climate change impacts and availability of energy resources);

- How is it possible that while emissions are decreasing temperature still increases? (dynamics of accumulation of carbon in the atmosphere, inertias);

- A new set of technologies will emerge in a few years and solve all problems (aforementioned dynamics of delays and inertias for new technologies);

- Why a faster growth of renewables implies a lower efficiency of the system? (feedback of the EROI of the system, lower net energy available to the society);

- Why if the temperature increase reached in this simulation is lower than the previous one, now we have surpassed a climate tipping point and not before? (probabilistic assessment, "low" probability catastrophic phenomena);

- It is impossible to find a scenario without collapse in this game! (wrong, the participants were not able to identify the actual leverage points of the system).

\subsubsection{Capacity to Bridge the Gap Between Science and Society}

The aforementioned insights attained by the participants of the game are central to current scientific research but most remain outside the public realm. Hence, the game has a significant capacity to bridge the gap between science and society. The game allows the players to discuss paradigmatic concepts which underline the functioning of our society, but are rarely publicly discussed, such as technological change or economic growth. For example, although the term "economic growth" was familiar to most participants, the game revealed that a significant number was not aware of its meaning 
(paradoxically even among those who were in favor of selecting a policy of economic growth in alternative scenarios). The game also brought to scene scientific discussions such as the relationship between economic growth and environmental impacts [68-70].

The game also stimulated conversations on the role of technology in contributing to solutions. A number of participants were initially skeptical about the results obtained in the simulations arguing that future new technologies would allow for high energy supply with low environmental costs. However, with the chosen analysis time frame (set for the mid-century 2050-80), decarbonization is required as soon as possible and thus, relies on existing technologies since new technological developments require substantial amounts of time to reach a significant share of the market. For example, the solar PV technology has been growing at annual global rates of over 50\% since 1995 and, nowadays, it barely surpasses $1 \%$ of world electricity generation [71]. Past energy transitions have been shown to be rather slow [72,73]. Hence, in the horizon to the mid-century, the effect of potential novel technologies is greatly reduced. The sense of time scarcity was also a key element in the discussions leading to the proposal of consistent alternative scenarios. The game also allowed the reproduction of more common public debates, such as the nuclear vs renewable energies controversy. When these conversations emerged, the facilitators would remind participants that electricity represents just a share of the total energy consumed in industrial countries, making up between $20 \%$ and $25 \%$ [74].

The game platform creates a gradual introduction to complex scientific phenomena such as the increasing probability of surpassing a climate tipping point in the next decades. These points, subject to large uncertainties and scientific knowledge gaps, are "low" probability ("surprise") catastrophic phenomena [6]. Hence, deep uncertainty, aversion to risk, climate and Earth science were introduced in the discussions.

Additionally, the performance of the game allows to bring closer policytargets such as the reduction of domestic emissions in the EU by $80 \%$ by 2050 compared to 1990 [66], or the most recent climate neutral Europe 2050 long-term strategy [75]. Overall, the successful application of the game is aligned with previous research which showed that simpler education technologies tend to score lower because of lower levels of engagement with inquiry processes and not actually resembling the work of scientists [76].

\subsubsection{Promote Discussion on Social Choices}

The discussion around the selection of the well-being target (proxied by final energy use per capita) allowed the large energy and material base of well-being in current industrialized societies to be discussed, confronting the large current inequality levels globally [77-79]. Its comparison with past societies with different socio-metabolic regimes, as well as with current human groups with radically different cultural values (e.g., those not aligned with consumerism such as Sieben Linden eco-village), allowed the cultural, social and ethical factors associated with human well-being to be highlighted $[80,81]$. The selection of the maximum global average temperature change, in combination with the information of potential climate tipping points, revealed different levels of aversion to risk from different participants, and consensus within each group was not always easy to attain. These discussions were new for many participants.

The simulation of successive alternative scenarios allowed the participants, through a process of trial-and-error, to identify the main drivers of unsustainability and, especially, to detect the high sensitivity of the outputs to the desired levels of future GDP per capita (economic growth). During game play, population size was often identified as an important driver bringing important ethical questions such as perceptions of freedom. The role of the facilitators in this point was key to explain that increases in affluence (typically measured in terms of GDPpc or (monetary) consumption per capita) are currently the main driver of environmental impacts globally [82-86], while other factors such as population growth and technology improvements have had to date less importance. Hence, during the game, often ethical choices related to sharing vs co-opting resources had to be explicitly taken. This is also related with the debate on which policy strategy is more appropriate to reduce 
inequalities: distribution vs economic growth. This is in contrast to daily life, when decisions which have (in)equality implications are often taken rather unconsciously. This led to some teams to develop (Degrowth [40]) scenarios where the end of inequality at a global level imply a reduction in material use of the richest countries in order to allow for the poorest to reach the basic standards of living. However, other teams took alternative approaches and tested extreme scenarios such as eco-fascist policies (e.g., drastic reduction of population <2000 million people by 2050) [87].

As any model, MEDEAS-World is a simplified representation of reality. Therefore, assumptions are made, some features are not considered and there are uncertainties about the values of the parameters. Particularly, demand-management/behavioral choices are almost absent; which is, by the way, a widespread limitation in the integrated assessment modelling field (see for example van Sluisveld et al., [88]), given the complexities of modelling these options. This is also related to the limits of "deterministic modelling" to project the evolution of variables in contexts which are very different from the starting point [89]. In this sense, the phases of assembly, debriefing and conclusions allow to have discussions "beyond the model", i.e., once the main conclusions had been extracted from the participative simulation, an active debate took place to identify the main behavioral, cultural and social changes which would be required in order to achieve sustainability in addition to technological ones. The following were identified: diet shifts, personal development, strong promotion of education, reduce working time, de-automate processes, redistribute wealth to live in more equitable societies, reduce mobility and shift to public transport, etc.

Finally, it should be highlighted that the pedagogical capacity of the game is enhanced by the flexibility of the game, which can be adapted to different contexts and types of participants (see next Section 3.2). For example, depending on the expertise level of the issues at stake, the game can be used as a tool to explain basic concepts and highlight the main human-Earth dynamics, but in those groups with a higher level of expertise, the game allows greater depth to be reached in the causes and alternative pathways to unsustainability.

\subsection{Reflections on the Game and Further Improvements}

With relation to game design, the participative method allows players to improve their knowledge by getting information from peers instead of traditional top-down, expert teaching. Peer learning allows a more individualized learning, peer teachers reinforce their own learning by instructing others, and students feel more comfortable and open when interacting with a peer [90].

Facilitators in Global Sustainability Crossroads require a basic understanding of the underlying MEDEAS-W model as well as moderating and teaching abilities. Depending on the level of the "participative culture" of the players, the role of the facilitator varies from discrete (e.g., only being consulted for clarification on the rules of the game or technical aspects of the model), to very active in order to balance participation. Their role is also key to effectively communicating the dangers of climate change to the participants, depending on their specific sensitivities (e.g., [91,92]), as well as redirecting eventual frustration and/or irritation when a team is not able to reach the self-stated objectives, so as to avoid despair and/or resignation, which are exactly the opposite of the pursued objectives of the game.

Among the different options given to participants during the game, hypotheses are the most complex to select, given the partially irreducible uncertainties in relation to the availability of fossil fuels in the future (e.g., [93]) or future climate change impacts (e.g., [94]).

There are trade-offs between the diversity of options to be selected by participants to run each simulation and the available time (i.e., more hypotheses and/or more measures would require more playing time). The current version of the game to be performed in 1 session of $\sim 4 \mathrm{~h}$ has been found to be a fair and consistent equilibrium between both. However, when the possibility arises of running the game in different sessions, more diversity of options could improve the players' understanding (e.g., aforementioned 5-session game applied in the classroom). 
In relation to the comparison of different game versions, the group dynamic has broadly been found more effective than the assembly one. Groups composed of smaller number of participants (max $\sim 6-8$ persons) generally lead to a richer and more diverse participation, which improved learning as well as reaching consensus for scenario inputs. The assembly version leads to a lower rate of participation (no interaction of "shy" players), without consensus for each option, given the complexities at stake and time constraints. The combination of voted measures may result in a "Frankenstein" scenario, which may not be felt by each individual participant as "his/her" scenario. In any case, this is the only option for big groups, when time availability is limited, or when the number of available facilitators is too reduced to perform the version with small groups. Another option would be an individual version of the game, which has only been performed internally within the developer research group. This version would allow the participants to directly test their personal scenarios, although the peer learning and discussion would be missing, together with a risk of a lack of reflection before performing each simulation.

The developer team received important and valuable feedback from participants, which allowed them to improve the dynamic of the game (e.g., idea to run a BAU scenario first on top of which to build the alternative scenario (different perceptions of what BAU trends are between different participants); expand the available options, etc.). Feedback has also proved to be important in helping to select priorities in the model development (inequalities, education, ethics, moral principles, etc.), reminding modellers, typically coming from a technical background, that energy is never just technological in any strict or narrow sense of the word, and is embedded in a wider system of science and technology dependent on social values, ethics and choices [80,81].

The following features may be incorporated in further developments of the game in order to improve the pedagogical capacity of the game:

- Introduce flexibility in the game in order to allow the players to check/modify decisions during each simulation.

- Downscaling of environmental impacts, socio-economic implications and potential solutions to country-level would help to bring the issues at stake closer to the players. This could be facilitated by developing game versions based on regional (EU) or country MEDEAS models $[95,96]$.

- Improve the socio-affective dimension of the dynamic. The simulations often show results which challenge the participants' earlier notions of how future may evolve. Hence, the game can generate conflicts (cognitive, values, etc.), both at personal and interpersonal level. Strategies for the proper management of these differences by the facilitators should be refined in order to channel them towards new cognitive syntheses leading to change and transformation processes [97].

- MEDEAS-World is a model under development: regularly update the game. Important dimensions are still not included in the game, such as the social (e.g., well-being and inequality).

- Apply participatory multi-criteria analysis to help participants to select the most favorable set of policies/attain objectives, dealing with the trade-offs in the transition to sustainability due to the incommensurability of the different dimensions of which it is made up: environmental (e.g., climate mitigation, land-use, and water), economic (monetary investments, welfare, etc.), social (e.g., inequality and gender) (e.g., [98]).

The developer team is open to perform the game upon invitation (as advertised in the group's website http://geeds.eu/). In the future, it is planned to make available the materials (interface, forms, etc.), together with additional documentation such as tutorials for facilitators and basic description of the underlying model, developing appropriate educative materials, so any person interested may independently perform and adapt the game to his/her purposes. The training of facilitators is critical given that research has shown that misconceptions and misunderstandings about many environmental issues, climate change included, are not only held by pupils but by teachers $[19,99]$. This would also allow the inclusion of the game in teaching programs. 


\section{Conclusions}

The origin of this work stems from the state-of the-art environmental integrated assessment model MEDEAS [36], which was at first developed to provide policy-guidance within the UE. However, the model developer team soon perceived the potential of applying the model also as a pedagogical tool. This work describes and qualitatively evaluates the pedagogical potential of the developed participatory simulation game Global Sustainability Crossroads, whose main objective is to improve the comprehension of the global sustainability conundrum to citizens, especially focusing on climate change and the potential alternatives available in the next few decades to reverse current trends. The novelty of the game rests on the global scope and the representation of the drivers of anthropogenic emissions within the MEDEAS-World model, combined with a participatory simulation group dynamic flexible enough to be adapted to a diversity of contexts and participants. A specific game interface has been developed to facilitate the use of the model by non-experts. The underlying model has been developed using System Dynamics, a methodology which has proved to be particularly well adapted to understand and address the multiple and interlinked factors involved in the sustainability crisis.

The game creates a virtual scenario where the participants are confronted with the design of climate mitigation strategies as well as the social, economic and environmental consequences of decisions at global level. Through the game, the participants discover soon the complexity of the problem and the difficulties to reach ideal solutions. In turn, these barriers motivate them in the search for alternative solutions. Plenary debates following simulations allow to connect global outcomes with the required local and personal behavior changes in relation to consumption choices and political participation. In this sense, the game follows the "think global, act local" ecologist motto to address environmental problems. The performance of 13 game workshops with $\sim 420$ players in a diversity of contexts and heterogeneous types of participants has shown it has a significant pedagogical potential: the game is able to generate discussions on crucial topics which are usually outside the public realm such as the relationship between economic growth and sustainability, the role of technology, how human desires are limited by biophysical constraints or the possibility of climate tipping points. Hence, the developed game allows the gap between scientific research and society to be bridged.

Up to now, a rigorous evaluation of the pedagogical efficacy of the game has not been performed, although the feedback from participants as well as the perception of teachers and facilitators indicates that it is substantial. Ongoing work is currently focused into the quantitative evaluation of the performance of the game with the final stable version of the game. Further work may focus on the downscaling of impacts potential solutions, which would contribute to improve the socio-affective dimension of the dynamic.

Supplementary Materials: The following are available online at http://www.mdpi.com/2071-1050/ 11/13/3672/s1, FORM1-HYP_Crossroads_EN; FORM2-BAU_Crossroads_EN; FORM3-OBJ_Crossroads_EN; FORM4-ALT_Crossroads_EN.

Author Contributions: Conceptualization, I.C.-P.; methodology, I.C.-P., D.Á.-A., and L.J.M.; software, D.A-A.; validation, I.C-P. and D.Á.-A.; investigation, I.C.-P., D.Á.-A., and L.J.M.; writing-original draft preparation, I.C.-P.; writing-review and editing, I.C.-P., D.Á.-A., and L.J.M.

Funding: Iñigo Capellán-Pérez acknowledges financial support from the Juan de la Cierva Research Fellowship of the Ministry of Economy and Competitiveness of Spain (no. FJCI-2016-28833).

Acknowledgments: The authors would like to thank all the participants in the different workshops performed of the game, as well as the people who have contributed as facilitators to the different versions of the game: Óscar Carpintero, Ignacio de Blas, Carmen Duce, José María Enríquez, Margarita Mediavilla and Gonzalo Parrado, from the Group of Energy, Economy and System Dynamics of the University of Valladolid; Ilaria Perisi, Davide Natalini, Jordi Solé, Sara Falsini from the MEDEAS Project; and Álvaro Campos Celador from the University of the Basque Country. We also gratefully thank Iñaki Arto for his calculations in order to obtain the final energy use and footprint for the countries in the WIOD database for the period 1995-2009.

Conflicts of Interest: The authors declare no conflict of interest. 


\section{Appendix A. Modelling Framework of MEDEAS-World Model}

MEDEAS-World (MEDEAS-W) is a global, one-region energy-economy-environment model (or integrated assessment model). It is a policy-simulation dynamic-recursive model which has been designed applying System Dynamics which facilitates the integration of knowledge from different perspectives and disciplines as well as the feedbacks from different subsystems. The model has been developed in Vensim DSS software for Windows Version 6.4E (x32), and is also available in Python open-source code (http://www.medeas.eu/, The model typically runs from 1995 to 2050 (although the simulation horizon may be extended to 2100 if necessary, e.g., when focusing on climate change issues). MEDEAS- $W$ is structured in seven main sub-modules: Economy, Energy, Infrastructures, Materials, Land Use, Social and Environmental Impact Indicators, and Climate Change (see Figure A1). The main variables connecting the different modules are represented by arrows.

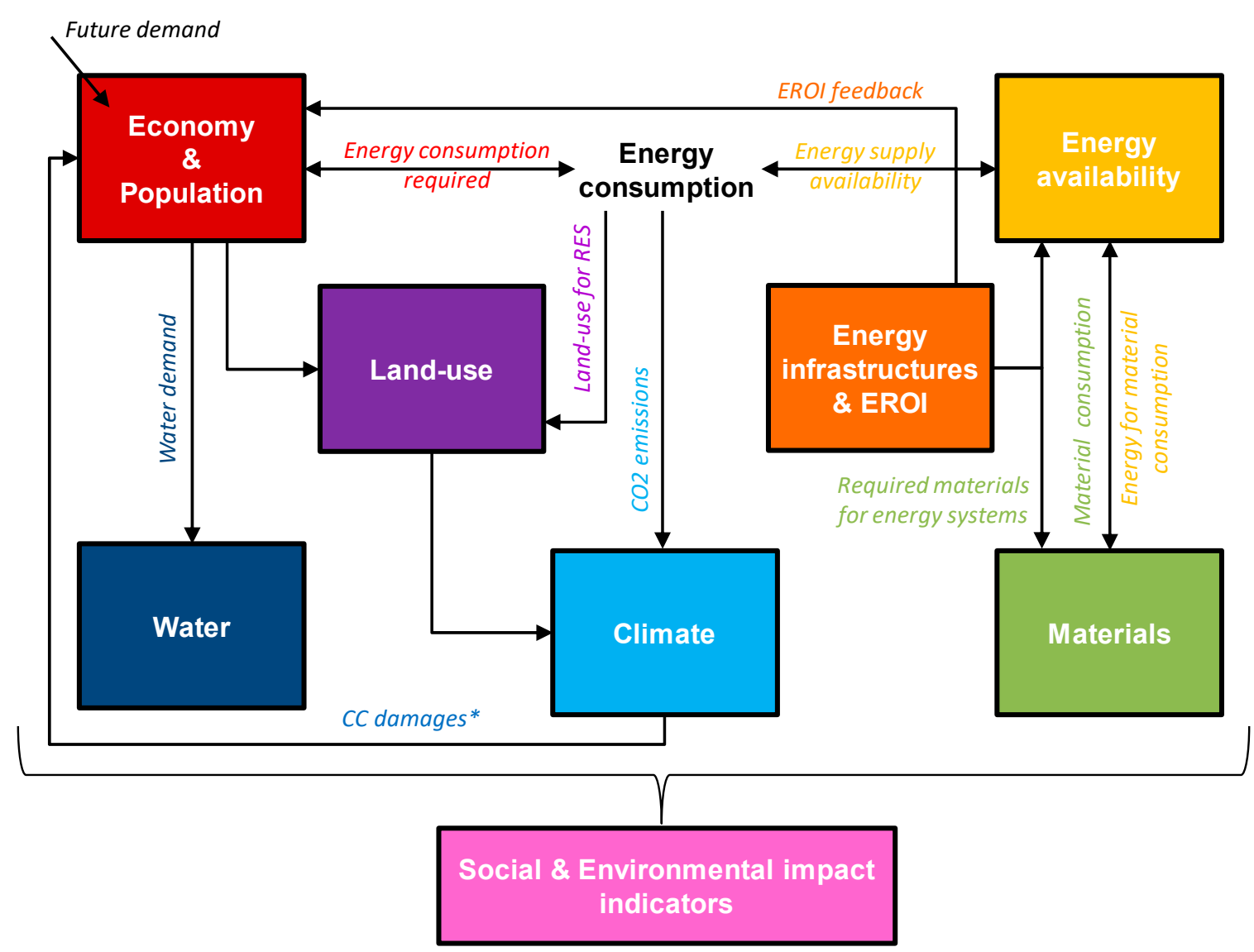

Figure A1. MEDEAS-World model schematic overview. Source: adaptation from [36]. CC: climate change; IOT: Input-ouput tables; NRE: non-renewable energies; RES: renewables. ${ }^{*}$ The climate change damage function can be specified by the user as a damage function or as an energy losses function.

The main characteristics of each module are:

- Economy and population: the global economy in MEDEAS is modelled assuming non-clearing markets (i.e., not forcing general equilibrium), demand-led growth and complementarity instead of perfect substitutability. Hence, production is determined by final demand and economic structure, combined with supply-side constraints such as energy availability. The economic structure is captured by the adaptation and dynamic integration of global WIOD input-output tables, resulting in 35 industries and 4 institutional sectors [100]. Final energy intensities by sector are obtained by combining information from the WIOD environmental accounts [101] and the 
IEA Balances (2018). Population evolves exogenously as defined by the user. See [102] for more details on this sub-module.

- Energy availability: this module includes the potential and availability of renewable and non-renewable energy resources, taking into account biophysical and temporal constraints. In particular, the availability of non-renewable energy resources depends on both stock and flow constraints [103-105]. In total, 25 energy sources and technologies, and 5 final fuels are considered (electricity, heat, solids, gases, and liquids), with large technological disaggregation. The intermittency of RES is considered in the framework, computing endogenous levels of overcapacities, storage and overgrids, depending on the penetration of variable RES technologies. This sub-module is mainly based on the previous model WoLiM [106]. Transportation is modelled in great detail, differentiating between different types of vehicles for households, as well as freight and passenger inland transport (see [36] for details).

- Energy infrastructures and EROI: This module represents power plants to generate electricity and heat, allowing planning and construction delays to be considered. A net energy approach is applied [107] endogenously and dynamically accounting for the EROI of both individual technologies and the EROI of the system. The demand of energy is affected by the variation of the EROI of the system.

- Materials: materials are required by the economy, with emphasis on those required for the construction and O\&M of alternative energy technologies [107]. Recycling policies are available.

- Land-use: this module currently mainly accounts for the land requirements of the RES energies.

- Water: this module allows calculating water use by type (blue, green and gray) by economic sector and for households.

- Climate: this module projects the climate change levels due to the GHG emissions generated by human societies (non-CO2 emissions are exogenously set, taking RCPs scenarios as reference [108]). The carbon and climate cycle is adapted from C-ROADS $[109,110]$. This module includes a damage function which translates increasing climate change levels into damages for the human systems [111].

- Social and environmental impacts: this module translates the "biophysical" results of the simulations into metrics related with social and environmental impacts. The objective of this module is to contextualize the implications for human societies in terms of well-being for each simulation.

The model dynamically operates as follows. For each period: first, a sectoral economic demand is estimated from an exogenous and dynamic GDPpc objective. The final energy demand required to meet production is obtained using energy-economy hybrid input-output analysis, and combining monetary output and energy intensities by final energy sources. Second, the energy sub-module computes the net available final energy supply, which may satisfy (or not) the required demand: the economy adapts to eventual fuel scarcity. Third, materials required to build, operate, maintain, dismantle, etc., are estimated. This allows the EROI of the system to be estimated as well as eventual material bottlenecks to be assessed (although material availability does not constrain economic output in the current model version). Fourth, the climate sub-module computes the GHG emissions, whose accumulation derives in a certain level of climate change, which in turn feeds back to the economic sectoral output. Additional land and water requirements are accounted for. Finally, the social and environmental impacts are computed.

For a detailed documentation of the MEDEAS-World model, see [36].

\section{Appendix B. Performed Game Workshops}

The game has been performed 13 times, in 2 countries (Spain and Italy), spanning a wide range of players (from 10 to 100 people) with a heterogeneous level of expertise, education and age (see Table A1). Depending on the number of players, available time and trained facilitators, different 
versions of the game were tested. In events outside the city where the research group developing the game is based, the group version was more difficult to perform due to practical reasons. The game was performed in a diversity of contexts, mostly in academic-teaching $(1,2,4-7,10,11,13)$, but also within internal events of environmental non-profit organizations $(3,12)$, open to civil society $(8)$ and with sustainability business practitioners (9). This diversity allowed a rich feedback which allowed to considerably enhance the game.

Table A1. Performed workshops of Global Sustainability Crossroads game from September 2017 to December 2018.

\begin{tabular}{|c|c|c|c|c|c|c|}
\hline $\begin{array}{c}\text { Event } \\
\text { Number }\end{array}$ & Event & Date & Place & $\begin{array}{l}\text { Number of } \\
\text { Participants }\end{array}$ & $\begin{array}{c}\text { Characterization of } \\
\text { Participants (Level } \\
\text { of Expertise/Age) }\end{array}$ & $\begin{array}{l}\text { Type of } \\
\text { Dynamic } \\
\text { Performed }\end{array}$ \\
\hline 1 & $\begin{array}{l}\text { Club of Rome } \\
\text { Summer } \\
\text { Academy }\end{array}$ & $9-9-2017$ & Florence (Italy) & $\sim 50$ & $\begin{array}{l}\text { Experts and } \\
\text { informed } \\
\text { activists/all ages }\end{array}$ & $\begin{array}{l}\text { Groups-1 } \\
\text { session }\end{array}$ \\
\hline 2 & $\begin{array}{l}\text { IV Course of } \\
\text { Ecological } \\
\text { Economics }\end{array}$ & $26-10-2017$ & $\begin{array}{l}\text { University of the } \\
\text { Basque Country, } \\
\text { Faculty of } \\
\text { Economics, } \\
\text { Bilbao (Spain) }\end{array}$ & $\sim 10$ & $\begin{array}{l}\text { Experts \& informed } \\
\text { activists/all ages }\end{array}$ & $\begin{array}{l}\text { Groups-1 } \\
\text { session }\end{array}$ \\
\hline 3 & $\begin{array}{l}\text { VII Congress of } \\
\text { Ecologistas en } \\
\text { Acción }^{3}\end{array}$ & $7-12-2017$ & $\begin{array}{l}\text { Valladolid } \\
\text { (Spain) }\end{array}$ & $\sim 40$ & $\begin{array}{c}\text { Informed } \\
\text { activists/all ages }\end{array}$ & $\begin{array}{l}\text { Groups-1 } \\
\text { session }\end{array}$ \\
\hline 4 & $\begin{array}{l}\text { Classroom } \\
\text { (Subject: } \\
\text { Education for } \\
\text { Peace and } \\
\text { Equality) }\end{array}$ & $6-3-2018$ & $\begin{array}{l}\text { Faculty of } \\
\text { Education of the } \\
\text { University of } \\
\text { Valladolid, } \\
\text { Segovia (Spain) }\end{array}$ & $\sim 25$ & $\begin{array}{c}\text { Students/18-19 } \\
\text { years }\end{array}$ & $\begin{array}{l}\text { Groups-1 } \\
\text { session }\end{array}$ \\
\hline 5 & $\begin{array}{l}\text { Classroom } \\
\text { (subject: Social } \\
\text { Responsibility of } \\
\text { Engineering) }\end{array}$ & $\begin{array}{l}\text { 2nd semester } \\
\text { 2017-2018 } \\
\text { course }\end{array}$ & $\begin{array}{l}\text { Faculty of } \\
\text { Industrial } \\
\text { Engineering of } \\
\text { the University of } \\
\text { Valladolid } \\
\text { (Spain) }\end{array}$ & $\sim 25$ & Students $/ 4$ th year & $\begin{array}{l}\text { Groups-5 } \\
\text { sessions }\end{array}$ \\
\hline 6 & $\begin{array}{c}\text { Classroom } \\
\text { (subject: } \\
\text { Engineering and } \\
\text { Society) }\end{array}$ & $\begin{array}{l}\text { 2nd semester } \\
\text { 2017-2018 } \\
\text { course }\end{array}$ & $\begin{array}{l}\text { Faculty of } \\
\text { Industrial } \\
\text { Engineering of } \\
\text { the University of } \\
\text { Valladolid } \\
\text { (Spain) }\end{array}$ & $\sim 25$ & Students /4th year & $\begin{array}{l}\text { Groups-5 } \\
\text { sessions }\end{array}$ \\
\hline 7 & $\begin{array}{c}\text { Classroom } \\
\text { (subject: } \\
\text { Engineering, } \\
\text { Technology and } \\
\text { Society) }\end{array}$ & $\begin{array}{l}\text { 2nd semester } \\
\text { 2017-2018 } \\
\text { course }\end{array}$ & $\begin{array}{l}\text { Faculty of } \\
\text { Industrial } \\
\text { Engineering of } \\
\text { the University of } \\
\text { Valladolid } \\
\text { (Spain) }\end{array}$ & $\sim 15$ & Students /4th year & $\begin{array}{l}\text { Groups-5 } \\
\text { sessions }\end{array}$ \\
\hline 8 & $\begin{array}{l}\text { "Playing to } \\
\text { Manage the } \\
\text { World" } 4 \text { (specific } \\
\text { event) }\end{array}$ & $20-3-2018$ & $\begin{array}{l}\text { Valladolid } \\
\text { (Spain) }\end{array}$ & $\sim 100$ & $\begin{array}{l}\text { Heterogeneous/all } \\
\text { ages }\end{array}$ & $\begin{array}{l}\text { Assembly-1 } \\
\text { session }\end{array}$ \\
\hline 9 & $\begin{array}{l}\text { 15th Conference } \\
\text { and Trade Fair of } \\
\text { Green Building }{ }^{5}\end{array}$ & $19-5-2018$ & $\begin{array}{c}\text { Aínsa, Huesca } \\
\text { (Spain) }\end{array}$ & $\sim 45$ & $\begin{array}{l}\text { Heterogeneous/all } \\
\text { ages }\end{array}$ & $\begin{array}{l}\text { Assembly-1 } \\
\text { session }\end{array}$ \\
\hline 10 & $\begin{array}{l}\text { Classroom } \\
\text { (subject: } \\
\text { Modelling- } \\
\text { Dynamics) }\end{array}$ & $\begin{array}{l}\text { 1st semester } \\
\text { 2018-19 } \\
\text { course }\end{array}$ & $\begin{array}{l}\text { Factulty of } \\
\text { Industrial } \\
\text { Engineering of } \\
\text { the University of } \\
\text { Valladolid } \\
\text { (Spain) }\end{array}$ & 4 & Students/4th year & $\begin{array}{l}\text { Groups-3 } \\
\text { sessions }\end{array}$ \\
\hline
\end{tabular}


Table A1. Cont.

\begin{tabular}{|c|c|c|c|c|c|c|}
\hline $\begin{array}{c}\text { Event } \\
\text { Number }\end{array}$ & Event & Date & Place & $\begin{array}{l}\text { Number of } \\
\text { Participants }\end{array}$ & $\begin{array}{c}\text { Characterization of } \\
\text { Participants (Level } \\
\text { of Expertise/Age) }\end{array}$ & $\begin{array}{c}\text { Type of } \\
\text { Dynamic } \\
\text { Performed }\end{array}$ \\
\hline 12 & $\begin{array}{c}\text { II EnergÉtica } \\
\text { cooperative } \\
\text { Energy Meeting }{ }^{7}\end{array}$ & $24-11-2018$ & Burgos (Spain) & $\sim 15$ & $\begin{array}{c}\text { Informed } \\
\text { activists/all ages }\end{array}$ & $\begin{array}{l}\text { Assembly-1 } \\
\text { session }\end{array}$ \\
\hline 13 & $\begin{array}{l}\text { Classroom } \\
\text { (Subject: } \\
\text { Consumer } \\
\text { behavior) }\end{array}$ & $\begin{array}{l}\text { 1st Semester } \\
\text { 2018-19 } \\
\text { course }\end{array}$ & $\begin{array}{l}\text { Faculty of } \\
\text { Commerce of the } \\
\text { University of } \\
\text { Valladolid } \\
\text { (Spain) }\end{array}$ & $\sim 40$ & Students/2nd year & $\begin{array}{l}\text { Groups-3 } \\
\text { sessions }\end{array}$ \\
\hline & Total & $\begin{array}{l}\text { Sept } \\
\text { 2017-Dec } \\
2018\end{array}$ & Spain and Italy & $\sim 420$ & $\begin{array}{c}\text { Heterogeneous/ } \\
\text { students/experts/ } \\
\text { informed activists/ } \\
\text { informed citizens/ } \\
\text { all ages }\end{array}$ & $\begin{array}{l}\text { Groups-1 } \\
\text { and } 5 \\
\text { sessions, } \\
\text { Assembly-1 } \\
\text { session }\end{array}$ \\
\hline
\end{tabular}

Notes: ${ }^{1}$ https://www.clubofrome.org/2017/05/17/summeracademy/; ${ }^{2}$ http://www.hegoa.ehu.es/articles/text/ iv_curso_de_economia_ecologica; ${ }^{3}$ https://www.ecologistasenaccion.org/SPIP/article35304.html; 4 http://ucc. uva.es/actividades/Jugando-a-gobernar-el-mundo/; 5 https:/villadeainsa.com/eventos/programa-15a-jornadasbioconstruccion/; ${ }^{6}$ https://www.ehu.eus/es/web/iraunkortasuna/ekonomia-ekologikoko-ikastaroak; 7 https:// energeticacoop.es/burgos-acoge-los-ii-encuentros-energeticos/.

\section{References}

1. Anderson, K.; Bows, A. A new paradigm for climate change. Nat. Clim. Chang. 2012, 2, 639-640. [CrossRef]

2. IPCC. Climate Change 2014: Synthesis Report; Contribution of Working Groups I, II and III to the Fifth Assessment Report of the Intergovernmental Panel on Climate Change; Cambridge University Press: Cambridge, UK; New York, NY, USA, 2014; Available online: https://www.ipcc.ch/report/ar5/syr/ (accessed on 1 June 2019).

3. Millennium Ecosystem Assessment (MEA). Ecosystems and Human Well-Being: Scenarios; Carpenter, S.R., Pingali, P.L., Bennett, E.M., Zurek, M.B., Eds.; Global Assessment Reports; Island Press: Washington, DC, USA, 2005; Volume 2, ISBN 1-55963-390-5.

4. Steffen, W.; Richardson, K.; Rockström, J.; Cornell, S.E.; Fetzer, I.; Bennett, E.M.; Biggs, R.; Carpenter, S.R.; de Vries, W.; de Wit, C.A.; et al. Planetary boundaries: Guiding human development on a changing planet. Science 2015, 347. [CrossRef] [PubMed]

5. Steffen, W.; Broadgate, W.; Deutsch, L.; Gaffney, O.; Ludwig, C. The trajectory of the Anthropocene: The Great Acceleration. Anthr. Rev. 2015, 2, 81-98. [CrossRef]

6. Lenton, T.M.; Held, H.; Kriegler, E.; Hall, J.W.; Lucht, W.; Rahmstorf, S.; Schellnhuber, H.J. Tipping elements in the Earth's climate system. Proc. Natl. Acad. Sci. USA 2008, 105, 1786-1793. [CrossRef] [PubMed]

7. Daily, G. Nature's Services: Societal Dependence on Natural Ecosystems; Island Press: Washington DC, USA, 1997.

8. Levin, S.A.; Carpenter, S.R.; Godfray, H.C.J.; Kinzig, A.P.; Loreau, M.; Losos, J.B.; Walker, B.; Wilcove, D.S. The Princeton Guide to Ecology; Princeton University Press: Princeton, NJ, USA, 2009.

9. Schneider, S.H.; Morton, L. The Primordial Bond Exploring Connections between Man and Nature through the Humanities and Sciences; Plenum Press: New York, NY, USA, 1981.

10. O'Neill, D.W.; Fanning, A.L.; Lamb, W.F.; Steinberger, J.K. A good life for all within planetary boundaries. Nat. Sustain. 2018, 1, 88-95. [CrossRef]

11. Bangay, C.; Blum, N. Education responses to climate change and quality: Two parts of the same agenda? Int. J. Educ. Dev. 2010, 30, 359-368. [CrossRef]

12. Sterman, J.D. Sustaining Sustainability: Creating a Systems Science in a Fragmented Academy and Polarized World. In Sustainability Science; Weinstein, M.P., Turner, R.E., Eds.; Springer: New York, NY, USA, 2012; ISBN 978-1-4614-3187-9. 
13. Sterman, J.D. Business Dynamics: Systems Thinking and Modeling for a Complex World; Irwin/McGraw-Hill: Boston, MA, USA, 2000; Volume 19.

14. Sterman, J.D. Learning in and about complex systems. Syst. Dyn. Rev. 1994, 10, 291-330. [CrossRef]

15. Alessi, S.; Kopainsky, B. System Dynamics and Simulation/Gaming: Overview. Simul. Gaming 2015, 46, 223-229. [CrossRef]

16. Groves, F.H.; Pugh, A.F. Cognitive Illusions as Hindrances to Learning Complex Environmental Issues. J. Sci. Educ. Technol. 2002, 11, 381-390. [CrossRef]

17. Puttick, G.; Tucker-Raymond, E. Building Systems from Scratch: An Exploratory Study of Students Learning About Climate Change. J. Sci. Educ. Technol. 2018, 27, 306-321. [CrossRef]

18. Rates, C.A.; Mulvey, B.K.; Feldon, D.F. Promoting Conceptual Change for Complex Systems Understanding: Outcomes of an Agent-Based Participatory Simulation. J. Sci. Educ. Technol. 2016, 25, 610-627. [CrossRef]

19. Papadimitriou, V. Prospective Primary Teachers' Understanding of Climate Change, Greenhouse Effect, and Ozone Layer Depletion. J. Sci. Educ. Technol. 2004, 13, 299-307. [CrossRef]

20. Gómez-Baggethun, E.; Naredo, J.M. In search of lost time: The rise and fall of limits to growth in international sustainability policy. Sustain. Sci. 2015, 10, 385-395. [CrossRef]

21. UNCED. Declaration on Environment and Development; United Nations Conference on Environment and Development: Rio de Janeiro, Brazil, 1992.

22. UNFCCC. United Nations Framework Convention on Climate Change; FCCC/INFORMAL/84 GE.05-62220 (E) 200705; United Nations: New York, NY, USA, 1992.

23. UN. Convention on Biological Diversity; United Nations: Rio de Janeiro, Brazil, 1992; Available online: https: //treaties.un.org/doc/Treaties/1992/06/19920605\%2008-44\%20PM/Ch_XXVII_08p.pdf (accessed on 2 July 2019).

24. UN. Resolution Adopted by the General Assembly on 25 September 2015; United Nations: Washington, DC, USA, 2015.

25. Ehrlich, P.R.; Kareiva, P.M.; Daily, G.C. Securing natural capital and expanding equity to rescale civilization. Nature 2012, 486, 68-73. [CrossRef] [PubMed]

26. Barab, S.; Dede, C. Games and Immersive Participatory Simulations for Science Education: An Emerging Type of Curricula. J. Sci. Educ. Technol. 2007, 16, 1-3. [CrossRef]

27. Li, M.-C.; Tsai, C.-C. Game-Based Learning in Science Education: A Review of Relevant Research. J. Sci. Educ. Technol. 2013, 22, 877-898. [CrossRef]

28. Tosteson, J.L. The Scientific World View, Information Technology, and Science Education: Closing the Gap between Knowledge-Generation and Knowledge-Consumption. J. Sci. Educ. Technol. 1997, 6, 273-284. [CrossRef]

29. Davis, F.D.; Bagozzi, R.P.; Warshaw, P.R. Extrinsic and Intrinsic Motivation to Use Computers in the Workplace1. J. Appl. Soc. Psychol. 1992, 22, 1111-1132. [CrossRef]

30. Hamari, J.; Koivisto, J.; Sarsa, H. Does Gamification Work?-A Literature Review of Empirical Studies on Gamification. In Proceedings of the 47th Hawaii International Conference on System Sciences (HICSS), Waikoloa, HI, USA, 6-9 January 2014; pp. 3025-3034.

31. Markopoulos, A.P.; Fragkou, A.; Kasidiaris, P.D.; Davim, J.P. Gamification in engineering education and professional training. Int. J. Mech. Eng. Educ. 2015, 43, 118-131. [CrossRef]

32. Karagiorgas, D.N.; Niemann, S. Gamification and Game-Based Learning. J. Educ. Technol. Syst. 2017, 45, 499-519. [CrossRef]

33. Swinerton, E.N. Environmental Gaming Simulations. J. Environ. Educ. 1972, 3, 49-52. [CrossRef]

34. Wu, J.S.; Lee, J.J. Climate change games as tools for education and engagement. Nat. Clim. Chang. 2015, 5, 413-418. [CrossRef]

35. Stanitsas, M.; Kirytopoulos, K.; Vareilles, E. Facilitating sustainability transition through serious games: A systematic literature review. J. Clean. Prod. 2019, 208, 924-936. [CrossRef]

36. Capellán-Pérez, I.; de Blas, I.; Nieto, J.; De Castro, C.; Miguel, L.J.; Mediavilla, M.; Carpintero, Ó.; Rodrigo, P.; Frechoso, F.; Cáceres, S. D4.1 MEDEAS Model and IOA Implementation at Global Geographical Level; MEDEAS: Barcelona, Spain, 2017.

37. Meadows, D. Leverage points. In Places to Intervene in a System; The Sustainability Institute: Hartland, VT, USA, 1999.

38. OECD. Towards Green Growth; Organisation for Economic Co-Operation and Development: Paris, France, 2011.

39. World Bank. Inclusive Green Growth: The Pathway to Sustainable Development; World Bank Publications: Washinton, DC, USA, 2012; ISBN 978-0-8213-9551-6. 
40. Demaria, F.; Schneider, F.; Sekulova, F.; Martinez-Alier, J. What is Degrowth? From an Activist Slogan to a Social Movement. Environ. Values 2013, 22, 191-215. [CrossRef]

41. Meadows, D.H.; Randers, J.; Meadows, D.L. The Limits to Growth: The 30-Year Update; Chelsea Green Publishing Company: White River Junction, VT, USA, 2004; ISBN 1-931498-51-2.

42. Meadows, D.H.; Meadows, D.L.; Randers, J. Beyond the Limits: Global Collapse or a Sustainable Future; Earthscan Publications Ltd.: London, UK, 1992.

43. Meadows, D.H.; Meadows, D.L.; Randers, J.; Behrens, W.W., III. The Limits to Growth; Universe Books: New York, USA, 1972; ISBN 0-87663-165-0.

44. Meadows, D. World3 and Stratagem: History, Goals, Assumptions, Implications. In Onishi, Akira (2009): Integrated Global Models of Sustainable Development; Eolss Publishers: Oxford, UK, 2009; Volume 1, pp. 104-123.

45. Meadows, D. Strategem; University of New Hampshire: Durham, NH, USA, 1984.

46. Meadows, D.L. Tools for Understanding the Limits to Growth: Comparing a Simulation and a Game. Simul. Gaming 2001, 32, 522-536. [CrossRef]

47. Meadows, D.; Fiddaman, T.; Shannon, D. Fish Banks, Ltd. A Microcomputer Assisted Group Simulation That Teaches Principles of Sustainable Management of Renewable Natural Resources; Laboratory for Interactive Learning, Hood House, University of New Hampshire: Durham, NH, USA, 1993; pp. 698-706.

48. McBurnett, L.R.; Hinrichs, M.M.; Seager, T.P.; Clark, S.S. Simulation Gaming Can Strengthen Experiential Education in Complex Infrastructure Systems. Simul. Gaming 2018, 49, 620-641. [CrossRef]

49. Rooney-Varga, J.N.; Sterman, J.D.; Fracassi, E.; Franck, T.; Kapmeier, F.; Kurker, V.; Johnston, E.; Jones, A.P.; Rath, K. Combining role-play with interactive simulation to motivate informed climate action: Evidence from the World Climate simulation. PLoS ONE 2018, 13, e0202877. [CrossRef] [PubMed]

50. Sterman, J.; Franck, T.; Fiddaman, T.; Jones, A.; McCauley, S.; Rice, P.; Sawin, E.; Siegel, L.; Rooney-Varga, J.N. World Climate: A Role-Play Simulation of Climate Negotiations. Simul. Gaming 2015, 46, 348-382. [CrossRef]

51. Lucas, J.; Escapa García, M.; González-Eguino, M. The Use of Role-Play Games in Teaching: The International Climate Negotiation Game; ADDI (University of the Basque Country): Vizcaya, Spain, 2016.

52. MIT. World Energy: A Climate and Energy Policy Negotiation Game. Available online: https://mitsloan.mit. edu/LearningEdge/simulations/worldenergy/Pages/default.aspx (accessed on 10 March 2018).

53. Kriegler, E.; Hall, J.W.; Held, H.; Dawson, R.; Schellnhuber, H.J. Imprecise probability assessment of tipping points in the climate system. Proc. Natl. Acad. Sci. USA 2009, 106, 5041-5046. [CrossRef]

54. Chen, J.C.; Martin, A.R. Role-Play Simulations as a Transformative Methodology in Environmental Education. J. Transform. Educ. 2015, 13, 85-102. [CrossRef]

55. Wang, J.; Feng, L.; Tang, X.; Bentley, Y.; Höök, M. The implications of fossil fuel supply constraints on climate change projections: A supply-side analysis. Futures 2017, 86, 58-72. [CrossRef]

56. Van Vuuren, D.P.; Kok, M.T.J.; Girod, B.; Lucas, P.L.; de Vries, B. Scenarios in Global Environmental Assessments: Key characteristics and lessons for future use. Glob. Environ. Chang. 2012, 22, 884-895. [CrossRef]

57. Leach, M.; Raworth, K.; Rockström, J. Between social and planetary boundaries: Navigating pathways in the safe and just space for humanity. In World Social Science Report 2013; Organisation for Economic Co-Operation and Development: Paris, France, 2013; pp. 84-89.

58. Cottrell, F. Energy and Society: The Relation between Energy, Social Change, and Economic Development; AuthorHouse: Bloomington, IA, USA, 2009; ISBN 978-1-4490-3169-5.

59. The Collapse of Complex Societies; Reprint ed.; Cambridge University Press: Cambridge, UK; New York, NY, USA, 1990; ISBN 978-0-521-38673-9.

60. White, L.A. Energy and the evolution of culture. Am. Anthropol. 1943, 45, 335-356. [CrossRef]

61. Arto, I.; Capellán-Pérez, I.; Lago, R.; Bueno, G.; Bermejo, R. The energy requirements of a developed world. Energy Sustain. Dev. 2016, 33, 1-13. [CrossRef]

62. Rao, N.D.; Riahi, K.; Grubler, A. Climate impacts of poverty eradication. Nat. Clim. Chang. 2014, 4, 749-751. [CrossRef]

63. WBGU. World in Transition 3: Towards Sustainable Energy Systems; Earthscan: London, UK; Sterling, VA, USA, 2003.

64. Lamb, W.F.; Steinberger, J.K. Human well-being and climate change mitigation. WIREs Clim. Chang. 2017, 8, e485. [CrossRef]

65. Akizu, O.; Bueno, G.; Barcena, I.; Kurt, E.; Topaloğlu, N.; Lopez-Guede, J.M. Contributions of Bottom-Up Energy Transitions in Germany: A Case Study Analysis. Energies 2018, 11, 849. [CrossRef] 
66. European Commission. A Roadmap for Moving to a Competitive low Carbon Economy in 2050; Communication from the Commission to the European Parliament, the Council, the European Economic and Social Committee and the Committee of the Regions; European Commission: Brussels, Belgium, 2011.

67. Hines, J.M.; Hungerford, H.R.; Tomera, A.N. Analysis and Synthesis of Research on Responsible Environmental Behavior: A Meta-Analysis. J. Environ. Educ. 1987, 18, 1-8. [CrossRef]

68. Arrow, K.; Bolin, B.; Costanza, R.; Dasgupta, P.; Folke, C.; Holling, C.S.; Jansson, B.-O.; Levin, S.; Mäler, K.-G.; Perrings, C.; et al. Economic growth, carrying capacity, and the environment. Ecol. Econ. 1995, 15, 91-95. [CrossRef]

69. Stern, D.I. The Rise and Fall of the Environmental Kuznets Curve. World Dev. 2004, 32, 1419-1439. [CrossRef]

70. UNEP. Decoupling Natural Resource Use and Environmental Impacts from Economic Growth; United Nations Environment Programme, 2011. Available online: http://wedocs.unep.org/handle/20.500.11822/9816 (accessed on 2 July 2019).

71. IRENA. $d b$ IRENA Resource; International Renewable Energy Agency: Masdar City, UAE, 2019; Available online: http://resourceirena.irena.org (accessed on 1 June 2019).

72. Fouquet, R. The slow search for solutions: Lessons from historical energy transitions by sector and service. Energy Policy 2010, 38, 6586-6596. [CrossRef]

73. Smil, V. Energy Transitions: History, Requirements, Prospects; Praeger: Santa Barbara, CA, USA, 2010; ISBN 0-313-38177-1.

74. IEA. IEA World Energy Statistics and Balances; World Energy Statistics and Balances (Database); IEA/OECD: Paris, France, 2019.

75. EC. A Clean Planet for All-A European Strategic Long-Term Vision for a Prosperous, Modern, Competitive and Climate Neutral Economy; European Commission: Brussels, Belgium, 2018.

76. Bush, D.; Sieber, R.; Seiler, G.; Chandler, M. Examining Educational Climate Change Technology: How Group Inquiry Work with Realistic Scientific Technology Alters Classroom Learning. J. Sci. Educ. Technol. 2018, 27, 147-164. [CrossRef]

77. Fischer-Kowalski, M.; Krausmann, F.; Pallua, I. A sociometabolic reading of the Anthropocene: Modes of subsistence, population size and human impact on Earth. Anthr. Rev. 2014, 1, 8-33. [CrossRef]

78. Haberl, H. The global socioeconomic energetic metabolism as a sustainability problem. Energy 2006, 31, 87-99. [CrossRef]

79. Krausmann, F.; Gingrich, S.; Eisenmenger, N.; Erb, K.-H.; Haberl, H.; Fischer-Kowalski, M. Growth in global materials use, GDP and population during the 20th century. Ecol. Econ. 2009, 68, 2696-2705. [CrossRef]

80. Frigo, G. Energy ethics, homogenization, and hegemony: A reflection on the traditional energy paradigm. Energy Res. Soc. Sci. 2017, 30, 7-17. [CrossRef]

81. Smith, J.; High, M.M. Exploring the anthropology of energy: Ethnography, energy and ethics. Energy Res. Soc. Sci. 2017, 30, 1-6. [CrossRef]

82. Arto, I.; Dietzenbacher, E. Drivers of the Growth in Global Greenhouse Gas Emissions. Environ. Sci. Technol. 2014, 48, 5388-5394. [CrossRef]

83. Feng, K.; Davis, S.J.; Sun, L.; Hubacek, K. Drivers of the US $\mathrm{CO}_{2}$ emissions 1997-2013. Nat. Commun. 2015, 6, 7714. [CrossRef]

84. Lan, J.; Malik, A.; Lenzen, M.; McBain, D.; Kanemoto, K. A structural decomposition analysis of global energy footprints. Appl. Energy 2016, 163, 436-451. [CrossRef]

85. Weinzettel, J.; Hertwich, E.G.; Peters, G.P.; Steen-Olsen, K.; Galli, A. Affluence drives the global displacement of land use. Glob. Environ. Chang. 2013, 23, 433-438. [CrossRef]

86. Wiedmann, T.O.; Schandl, H.; Lenzen, M.; Moran, D.; Suh, S.; West, J.; Kanemoto, K. The material footprint of nations. Proc. Natl. Acad. Sci. USA 2013, 112, 6271-6276. [CrossRef] [PubMed]

87. Amery, C. Hitler als Vorläufer Auschwitz-Der Beginn des 21 Jahrhunderts? Luchterhand Literaturverlag: München, Germany, 2002; ISBN 3-630-62027-2.

88. van Sluisveld, M.A.E.; Martínez, S.H.; Daioglou, V.; van Vuuren, D.P. Exploring the implications of lifestyle change in $2{ }^{\circ} \mathrm{C}$ mitigation scenarios using the IMAGE integrated assessment model. Technol. Forecasting Soc. Chang. 2016, 102, 309-319. [CrossRef]

89. Dreborg, K.H. Essence of backcasting. Futures 1996, 28, 813-828. [CrossRef]

90. Johnson, D.W.; Johnson, R.T. Promoting Constructive Student-Student Relationships through Cooperative Learning; Minnesota University: Minneapolis, MN, USA, 1980. 
91. Dickinson, J.L.; Crain, R.; Yalowitz, S.; Cherry, T.M. How Framing Climate Change Influences Citizen Scientists' Intentions to Do Something About It. J. Environ. Educ. 2013, 44, 145-158. [CrossRef]

92. Dubois, B.; Krasny, M.E. Educating with resilience in mind: Addressing climate change in post-Sandy New York City. J. Environ. Educ. 2016, 47, 255-270. [CrossRef]

93. Capellán-Pérez, I.; Arto, I.; Polanco-Martínez, J.M.; González-Eguino, M.; Neumann, M.B. Likelihood of climate change pathways under uncertainty on fossil fuel resource availability. Energy Environ. Sci. 2016, 9 , 2482-2496. [CrossRef]

94. Dietz, S.; Stern, N. Endogenous Growth, Convexity of Damage and Climate Risk: How Nordhaus' Framework Supports Deep Cuts in Carbon Emissions. Econ. J. 2015, 125, 574-620. [CrossRef]

95. De Blas Sanz, I.; Capellán-Pérez, I.; Carpintero Redondo, Ó.; De Castro, C.; Frechoso, F.; Lobejón, L.F.; Lomas Huertas, P.L.; Mediavilla, M.; Miguel, L.J.; Nieto, J.; et al. D4.2 MEDEAS Model and IOA Implementation at European Geographical Level; MEDEAS Project: Barcelona, Spain, 2018.

96. Álvarez Antelo, D.; de Blas Sanz, I.; Capellán-Pérez, I.; Carpintero Redondo, Ó.; De Castro, C.; Frechoso, F.; Lobejón, L.F.; Lomas Huertas, P.L.; Mediavilla, M.; Miguel, L.J.; et al. D4.3 MEDEAS Model and IOA Implementation at Country Level: the Cases of Austria and Bulgaria; MEDEAS Project: Barcelona, Spain, 2018.

97. Hudlicka, E. Affective gaming in education, training and therapy: Motivation, requirements, techniques. In Handbook of Research on Improving Learning and Motivation through Educational Games: Multidisciplinary Approaches; IGI Global: Hershey, PA, USA, 2011; pp. 482-511. ISBN 978-1-60960-495-0.

98. Kowalski, K.; Stagl, S.; Madlener, R.; Omann, I. Sustainable energy futures: Methodological challenges in combining scenarios and participatory multi-criteria analysis. Eur. J. Oper. Res. 2009, 197, 1063-1074. [CrossRef]

99. Mortensen, L.L. Teacher Education for Sustainability. I. Global Change Education: The Scientific Foundation for Sustainability. J. Sci. Educ. Technol. 2000, 9, 27-36. [CrossRef]

100. Dietzenbacher, E.; Los, B.; Stehrer, R.; Timmer, M.; de Vries, G. The Construction of World Input-Output Tables in the Wiod Project. Econ. Syst. Res. 2013, 25, 71-98. [CrossRef]

101. Genty, A.; Arto, I.; Neuwahl, F. Final Database of Environmental Satellite Accounts: Technical Report on Their Compilation. WIOD Deliverable 4.6.. 2012. Available online: http://www.wiod.org/publications/source_docs/ Environmental_Sources.pdf (accessed on 1 June 2019).

102. Nieto, J.; Carpintero, Ó.; Miguel, L.J.; de Blas, I. Macroeconomic Modelling under Energy Constraints: Global Low Carbon Transition Scenarios; Working Paper; University of Valladolid: Valladolid, Spain, 2019.

103. Campbell, C.J.; Laherrère, J. The end of cheap oil. Sci. Am. 1998, 278, 60-65. [CrossRef]

104. Kerschner, C.; Capellán-Pérez, I. Peak-Oil and Ecological Economics. In Routdlege Handbook of Ecological Economics: Nature and Society; Spash, C.L., Ed.; Routledge: Abingdon, UK, 2017; pp. 425-435.

105. Mohr, S.H.; Wang, J.; Ellem, G.; Ward, J.; Giurco, D. Projection of world fossil fuels by country. Fuel 2015, 141, 120-135. [CrossRef]

106. Capellán-Pérez, I.; Mediavilla, M.; de Castro, C.; Carpintero, Ó.; Miguel, L.J. Fossil fuel depletion and socio-economic scenarios: An integrated approach. Energy 2014, 77, 641-666. [CrossRef]

107. Capellán-Pérez, I.; De Castro, C.; Miguel, L.J. Dynamic Energy Return on Energy Investment (EROI) and Material Requirements in Scenarios of Global Transition to Renewable Energies; Working Paper; University of Valladolid: Valladolid, Spain, 2019.

108. Van Vuuren, D.P.; Edmonds, J.A.; Kainuma, M.; Riahi, K.; Weyant, J. A special issue on the RCPs. Clim. Chang. 2011, 109, 1. [CrossRef]

109. Fiddaman, T.; Siegel, L.S.; Sawin, E.; Jones, A.P.; Sterman, J. C-ROADS Simulator Reference Guide; Ventana Systems, Climate Interactive and MIT: Cambridge, MA, USA, 2016.

110. Sterman, J.; Fiddaman, T.; Franck, T.; Jones, A.; McCauley, S.; Rice, P.; Sawin, E.; Siegel, L. Climate interactive: The C-ROADS climate policy model. Syst. Dyn. Rev. 2012, 28, 295-305. [CrossRef]

111. Capellán-Pérez, I.; de Castro, C. Integration of Global Environmental Change Threat to Human Societies in Energy-Economy-Environment Models. In Proceedings of the 12th Conference of the European Society for Ecological Economics, Budapest, Hungary, 20-23 June 2017.

(C) 2019 by the authors. Licensee MDPI, Basel, Switzerland. This article is an open access article distributed under the terms and conditions of the Creative Commons Attribution (CC BY) license (http://creativecommons.org/licenses/by/4.0/). 